\title{
sciendo USE OF THE DECISION TABLE FOR SUPPORTING MANAGEMENT PROCESS IN MINING COMPANIES
}

doi:10.2478/mape-2018-0074

Date of submission of the article to the Editor: 03/2018

Date of acceptance of the article by the Editor: 07/2018
MAPE 2018, volume 1, issue 1, pp. 587-593

\author{
MSc. Kinga Stecuła \\ Dr hab. inż. Jarosław Brodny \\ Silesian University of Technology, Poland
}

\author{
PhD. Mikheil Chikhradze \\ Georgian Technical University, Georgia
}

\begin{abstract}
The article presents a proposal of use a decision table to support the decision-making process in scope of maintenance management in mining companies. In particular, it refers to decisions related to evaluation and improvement of mining machinery use in the mining production process. The article presents the theoretical foundations of decision tables building and characteristics of the most important stages of creating this table. This whole process was tried to refer specifically the mining industry. For this reason, during construction of the decision tables, the results of research on the effectiveness of the selected mining machines were used. The conducted research provided a lot of data, information and knowledge on the work of the particular mining machines, especially regarding the number and reasons for unplanned breaks during the machines' work. The developed decision table will consist of conditions, rules and actions whose purpose is to define the recommendations for the particular groups of participants in the mining production process. The obtained results will form the basis for the development of the recommendations and proposals of actions to improve the level of use of mining machines. The authors focused mainly on the practical use of tables to support the decisionmaking process regarding maintenance and improvement of effectiveness of mining machines. The obtained results confirm the validity of the adopted assumptions. Decision tables can become an important tool that supports the decision-making process within mining companies.
\end{abstract}

Keywords: decision table, knowledge, mining company, decision-making support.

\section{INTRODUCTION}

There is a lot of discussion these days regarding knowledge-based economy. Information and knowledge have become the key and valuable resources of enterprises in practically every kind of industry. Knowledge can be variously defined and divided into different types. One of the divisions includes four categories of knowledge which include: know-what, knowwhy, know-how and know-who (Lundvall, Johnson, 1994). Results of the work depend on knowing who is supposed to perform the action, why and how they have to do it. When planning and organizing work, various decisions, which will affect the future work, must be taken. Therefore, knowledge plays an important role in the decision-making process. At each stage of the enterprise's operation, managers face the necessity of making decisions and setting goals and directions. There are different ways to make decisions - for example, intuitive, probability-based, negotiation, group, individual and others. It is difficult to decide which methods are the most effective in making decisions. However, it can be claimed that the more knowledge one has about a given problem, there is a greater chance that the decision will be optimal and will bring the expected results. For this reason, before making a decision, it is necessary to gather as much knowledge as possible, organize it and take steps based on it. One of the tools to support the decision-making process is the decision table. It has been assumed that this tool can be used to support decisions in a mining 
company in the field of improving the effectiveness of machines. The article presents the characteristics of the decision table and the proposal of using this table as the basis for the development of an advisory system within the mining enterprise.

\section{CHARACTERISTIC OF THE DECISION TABLE}

With the decision table method, the information contained in the tables is used in an algorithmic manner. The table can even consist of a very large number of possible decision situations. It depends on the needs and expectations of users. The table is a set of decision rules which can also be presented in the form of block diagrams (Partyka, 1996). The decision tables are a classical method but combined with modern methods of design and management they can become an original, helpful and effective tool supporting the decision-making process. Thanks to the tables, it is easy and clear to define the actions which should be taken after meeting the given conditions. The tables are a problem-solving technique. They make it possible to check whether all possible test results have been taken into account. The tables show the relation between the reason (conditions) and the result (actions). The advantage of decision tables is the possibility of presenting complex relationships in a clear and transparent way. The decision tables can be used at all stages of the information systems designing. They pass on the logic of conduct to other people, eliminate redundant information, provide accuracy and facilitate programming (Pollack et al. 1975).

As M. Partyka points out, many authors treat the decision tables as a means of analysis and documentation of the system which complements the classic schemes of searching for and modifying solutions (Partyka, 1996). The basis for the construction of the decision tables is the condition: "If ..., then ...". This condition comes from mathematics, and more specifically, from its section of logic (Mostowski, 1948). In order to determine the sense of sentences in mathematics, words such as "and", "or", "if ..., then ...", "not" and others are used. They are called logical connectives and the most well-known are: negation, conjunction, disjunction, implication and biconditional. The implication (conditional) consists of the antecedent and the consequent. It is expressed by the following formula:

$$
p \rightarrow q
$$

where:

" $p$ " is the antecedent and " $q$ " is the consequent.

The antecedent is often called the assumption and the consequent - the thesis (Mostowski, 1948). The implication should be read "if ..., then ..." and it is false only if its antecedent is true and the consequent false.

Decision tables are algorithmic schemes of information flow. They consist of a set of decision rules that describe arrangement of conditions to take the selected activities. Every decision table must be divided into four basic parts which are composed of (Partyka, 1996):

- a set of conditions,

- a set of actions,

- a set of values (indicators) of conditions,

- a set of values (indicators) of actions.

A set of conditions ("if..." expressions) defines variables that affect the decision system. A set of actions ("then..." expressions) contains all activities that result from a set of conditions. The set of condition values consists of symbols like "Y" (yes) or 1, "N" (no) or 0 and "-" (nothing) which determine whether a given condition is met or not met or whether it affects a given decision. The set of actions values contains symbols e.g. "X" which mean that after fulfilling given conditions, given actions should be taken (Partyka, 1996). A very important term related to conditions and actions is the decision rule. It describes the condition or conditions which must be met in order for a given action or actions to be taken. 
A decision rule is a combination of conditions and actions that occur in a given decision situation (Wrycza, 1999). Figure 1 shows the construction of a classic decision table.

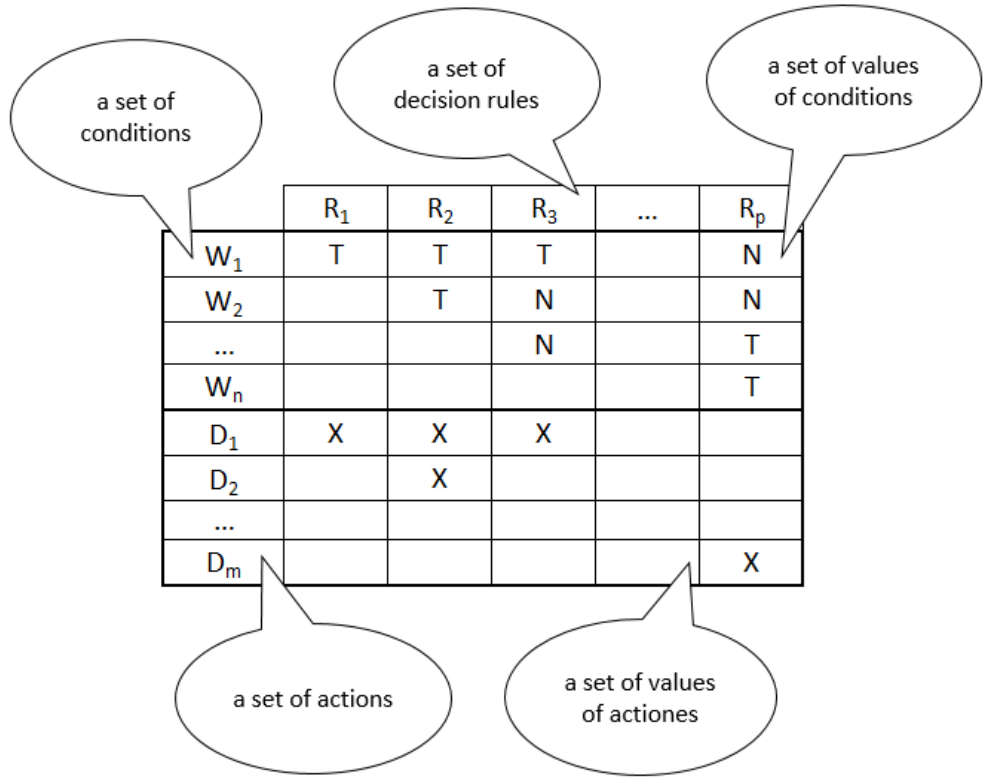

Fig. 1. The construction of a classic decision table

When a binary description of conditions is adopted (e.g., "T" / "N", "0" / "1", etc.), the maximum number of rules is $2^{n}$, where $n$ is a natural number standing for the number of conditions. In practice, fewer rules than $2^{n}$ are being considered (Wrycza, 1999).

Due to the fact that the tables contain decision rules, they can be presented in the form of block diagrams (Partyka, 1996). The conditions, rules and actions can be saved both in table and block forms. Figure 2 shows an example of decision making block diagram.

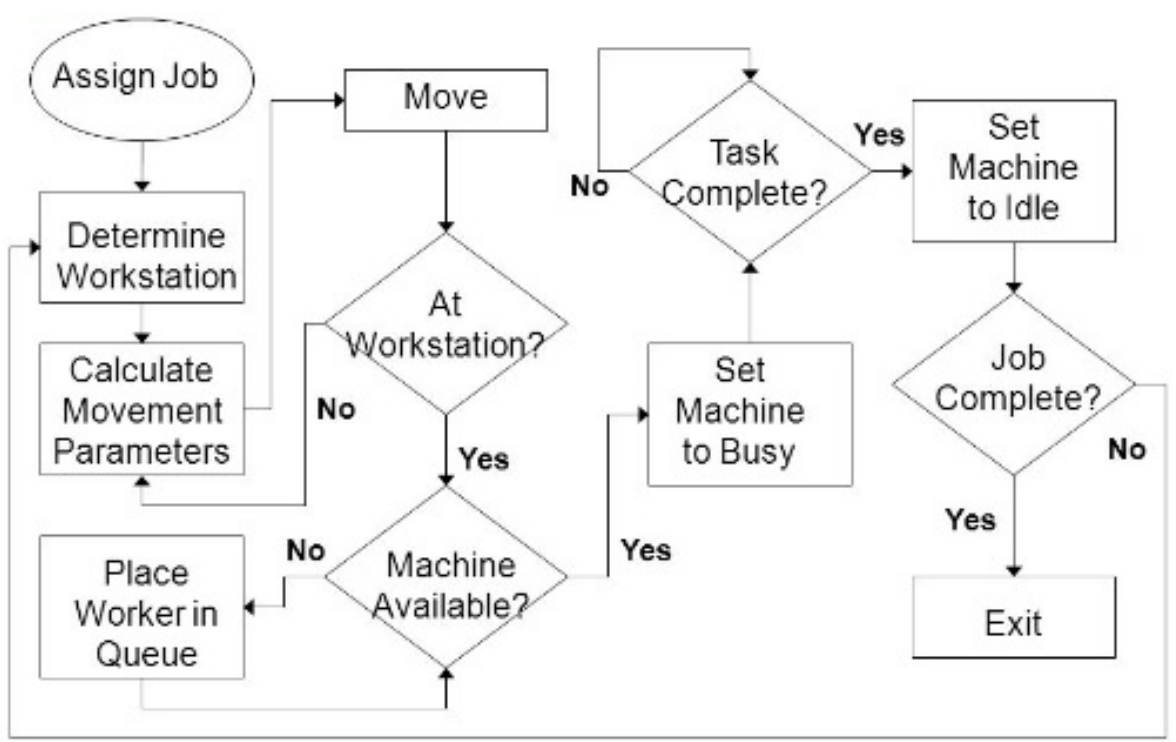

Fig. 2. An example of decision making block diagram

Source: (Jolly et al. 2015).

Before building a decision table, a specific decision problem should be determined. Next, a procedure of selecting the best variant should be developed. When formulating the conditions of the decision table, the hierarchy of importance must be established. The whole table should be coherent. Defining the conditions and actions must take place after gathering as much information and knowledge as possible, conducting interviews with experts, and 
making observations or consultations (Paszek and Partyka, 2014). Modularity, aggregation, decomposition or formalization of specific stages can be used to increase complexity of the table (Partyka and Paszek, 2017). The next chapter presents and discusses the possibility of using a decision table within an enterprise from the specific industry of mining.

\section{APPLICATION OF THE DECISION TABLE IN THE MINING COMPANY}

The conducted research concerns the level of the use of the machines in the mining production process (Brodny et al. 2016; Stecuła et al. 2017; Stecuła and Brodny, 2017). The research concerns machines included in the mechanized longwall system. They work underground in very difficult and non-predictable operating conditions. These machines include a longwall shearer, an armored face conveyor, a beam stage loader and a crusher. These machines form a serial structure system from a reliability point of view. In terms of research, the parameters for each of these machines were identified and selected. Subsequently, these parameters were subjected to numerous analyses. The parameters concerned the operation of individual machines. In the case of the longwall shearer, the analyzed parameters were currents consumed by the motors of cutting heads, feed motors and the hydraulic pump motor. The parameters of individual machines created several databases which made it possible to make many analyses of the machines' operation. These data were very detailed, accurate and highly reliable.

The data made it possible to identify work and breaks in the operation of mining machines. Then, these breaks were quantified, but also presented in terms of frequency of their occurrence. In addition, the breaks were completed with knowledge about their causes. This knowledge had a different character - it was both explicit and tacit knowledge. This knowledge was obtained thanks to numerous expert interviews and observations of the machines. Identification of the breaks in the machines' work and supplementation of their causes were made by using the knowledge, which enabled profound analyses of the operation of mining machinery.

Above, a brief description of only of a part of the research that is currently conducted in the mining enterprise is presented. One of the next stages of the research is to determine the recommendations for selected groups of participants in the production process in a mining company. These recommendations will concern the evaluation and improvement of the use of mining machines and identification of the reasons for unplanned breaks during the production process.

Recommendations should refer to activities that will be taken within the selected areas of the mining enterprise depending on the results of work and breaks in work analyses, as well as the reasons for these breaks. For this purpose, decision tables will be used to prepare a set of conditions, rules and actions that will be taken by the individual participants or groups of participants in the production process. Planning and taking action is not easy due to the specific nature of the mining industry. The mining process is influenced by various factors that are often unpredictable and very dangerous. For this reason, it is necessary to include natural, technical, technological, organizational and other factors in the research. The specificity of the mining production process is linked with the occurrence of various natural hazards (Tutak, 2017; Tutak and Brodny, 2018). Therefore, taking actions in the field of work safety, work organization, securing mining excavations with modern roof supports (Szurgacz and Brodny, 2017), increasing machine effectiveness, and organizing trainings (Palka et al. 2017) and in many other fields is crucial for mining.

In order to build decision tables to support decision making in a mining company, it is necessary to determine what will form a set of conditions, as well as a set of activities. To determine a set of conditions and decisions resulting from their fulfillment, many activities and analyses will be conducted. The content that will fill the decision table will depend on the results of previous research stages. Figure 3 presents a scheme of input elements which will 
be the starting point for the development of the decision table. The table will be, in turn, the basis of an advisory system on the use of mining machinery within the mining company.

The first key element for creating the conditions of the decision table is the analysis of individual parameters of the mining machines' operation. These parameters stand for the data (in the figure - "DATA ANALYSES"). Data analyses show the areas that generate the biggest losses for the enterprise in the area of machines' work. For example, they are able to identify a motor that does not consume current at the given moment. Thanks to this information, it is possible to determine what the reason for the breaks is - e.g. which part, subassembly etc. of a given machine generates a problem. The data analyses are supplemented with the analyses of other factors (in the figure - "FACTORS ANALYSES") which influence the use of machines. They include quantitative and qualitative analyses of an excavated material which is the final product of the cutting process. The possible contribution of the selected factors in the use of machines is also analyzed.

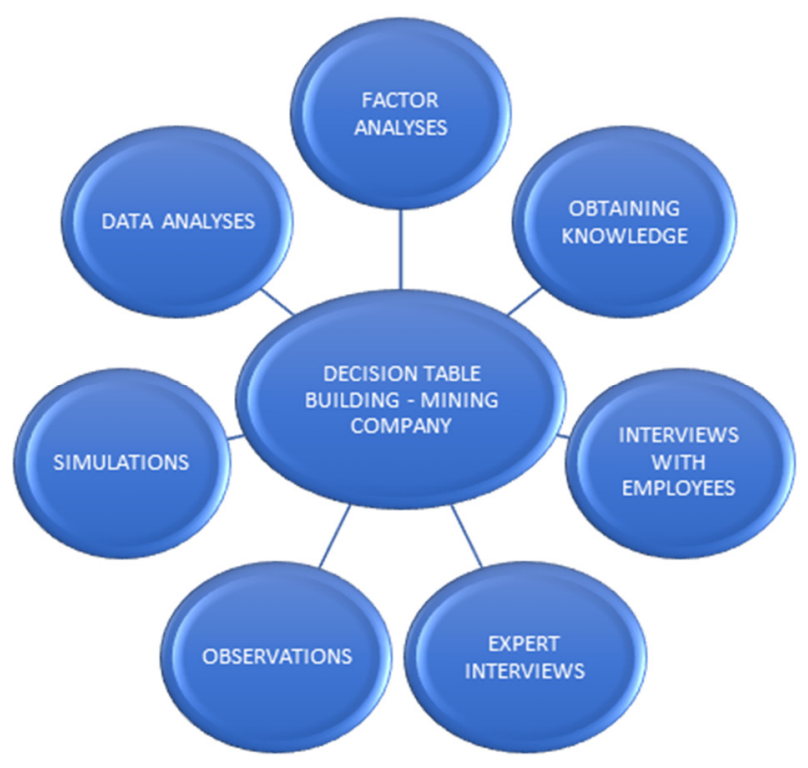

Fig. 3. Input elements to build the decision table as the basis of the advisory system within the mining company.

Another analyzed element is the history of the machines' work, which is data on negative events in the operation of the machines from the past. The subsequent input element for the decision table building is obtaining knowledge about the work of the machines (in the figure "OBTAINING KNOWLEDGE"). The obtained knowledge refers not only to work time, break time but also to the causes of the breaks in the work of the individual machines, as well as other factors which affect the mining, loading or transporting of the excavated material. It is worth noting that this knowledge has a dual character. It is divided into explicit and tacit knowledge. One of the most difficult stages is obtaining the tacit knowledge because it is associated with specific employees (in the figure - "INTERVIEWS WITH EMPLOYEES") directly responsible for the work of the machines. Often these employees do not share this knowledge for many reasons. Thanks to the disclosure of knowledge, it is possible to determine the causes of breaks in the operation of the machines and divide them into categories. Examples of such categories are mining, electrical, mechanical, hydraulic and others (Stecuła, et al 2017). A very important element to determine a set of action within a decision table is conducting interviews with mine employees and with experts (in the figure - "EXPERT INTERVIEWS"). Thanks to these interviews, it is possible to specify the circumstances and guidelines for taking selected actions. 
Another important element is the observation of the operation of mining machines in various departments of the enterprise (in the figure - "OBSERVATIONS"). After building a decision table, it is extremely important to check the accuracy of all rules and validate the solution which will be possible by using simulation methods (in the figure - "SIMULATIONS").

The decision table will consist of many conditions that will be included in both text and numerical forms. The numerical form will refer to the values of indicators, e.g., the quality index of the excavated material expressed in percentage. The conditions and actions included in the table will depend on the results of the research stages described above which are currently last.

\section{CONCLUSION}

The decision tables are a classic method supporting the decision-making process. Combined with modern methods of design and management, they can become an original and effective tool for supporting the decision-making process. The decision tables are a set of conditions and actions that organize information and knowledge. The transparency of the presentation of the content and the lack of redundancy or too much complexity make the tables a very helpful method. They show the relation between the cause and the effect.

In the article, the authors presented a proposal of using a decision table to support the decision-making process in a mining company. The decisions in the research concern the improvement of the use of mining machines in the mining production process. The authors presented the stage of preparing input elements to build the decision table. These elements include the results of the previously conducted research stages. They included: analyses of the mining machines operating parameters and obtaining explicit and tacit knowledge about the machines' work and breaks during this work, as well as knowledge about the causes of these breaks, analyses of various factors affecting the operation of machines, observations of machines, interviews with employees and experts, as well as simulations of the rules and actions developed in the table. All these stages will allow to build a decision table that will help to select the specific actions depending on the existing conditions.

\section{ACKNOWLEDGEMENTS}

Data, used in the paper, is the result of the work titled "Development of intelligent production methods as well as work and life environments in the context of production engineering challenges", symbol 13/030/BK_18/0039.

\section{REFERENCES}

Brodny, J., Stecuła, K., Tutak, M. (2016). Application of the TPM strategy to analyze the effectiveness of using a set of mining machines. Proceedings of 16th International Multidisciplinary Scientific GeoConferences. SGEM2016, 1(II), Albena Bulgaria, pp. 65-72.

Jolly, A., Oleson II, R., Kaup, D. J. (2015). Pedestrain Cellular Automata and Industrial Process Simulation.

Lundvall, B. A., Johnson, B. (1994). The learning economy. Journal of Industry Studies, 1(2).

Mostowski, A. (1948). Logika matematyczna. Warszawa - Wrocław: Instytut Matematyczny Polskiej Akademii Nauk.

Palka, D., Brodny, J. Stecula, K. (2017). Modern Means of Production and the Staff Awareness of the Technical in the Plant of the Mining Industry. In: CBU International Conference Proceedings 2017: Innovations in Science and Education, 5, pp. 1190-1194.

Partyka, M. A. (1996). Wybrane zagadnienia logiki i heurystyki w inżynierii projektowania i zarządzania. Opole: Wyższa Szkoła Inżynierska w Opolu.

Partyka, M., Paszek, A. (2017). Możliwości zastosowania tablic decyzyjnych w inżynierii projektowania konstrukcyjnego i technologicznego. In: Napędy i Sterowanie.

Paszek, A., Partyka, M. (2014). Zastosowanie tablic decyzyjnych w opracowaniu reprezentacji wiedzy technologicznej. In: R. Knosala, ed., Innowacje w zarządzaniu i Inżynierii Produkcji. Opole: Oficyna Wydawnicza Polskiego Towarzystwa Zarządzania Produkcją.

Pollack, S. L., Hicks, H. T., Harrison, W. J. (1975). Tablice decyzyjne. Warszawa: Państwowe Wydawnictwo Naukowe. 
Stecuła, K., Brodny, J. (2017). Generating knowledge about the downtime of the machines in the example of mining enterprise. In: Proceedings of 17th International Multidisciplinary Scientific GeoConferences SGEM 2017, 17(13), Exploration and Mining. Albena Bulgaria, pp. 359-366.

Stecula, K., Brodny, J., Tutak, M. (2017). Use of Intelligent Informatics Module for Registration and Assessment of Causes of Breaks in Selected Mining Machines. In: A. Burduk, D. Mazurkiewicz, ed., Intelligent Systems in Production Engineering and Maintenance - ISPEM. Advances in Intelligent Systems and Computing 637, Proceedings of the First International Conference on Intelligent Systems in Production Engineering and Maintenance, pp. 74-84.

Stecuła, K., Tutak, M., Brodny, J. (2017). Application of Chosen Elements from Japanese Production and Maintenance Management Philosophies in Polish Coal Mines. 17th International Multidisciplinary Scientific Geoconference SGEM 2017, 17(13), pp. 93-100.

Szurgacz, D., Brodny, J. (2017). Role and Relevance of an Electro Control System for the Operation of a Powered Roof Support. 17th International Multidisciplinary Scientific Geoconference SGEM 2017, 17(13), pp. 781-788.

Tutak, M. (2017). Analysis of varying levels of methane emissions from coal mines in Poland. Vienna GREEN Conference Proceedings, 17(43), pp. 301-308.

Tutak, M., Brodny, J. (2018). Impact of type of the roof rocks on location and range of endogenous fires particular hazard zone by in goaf with caving. E3S Web Conferences, 29, pp. 2267-1242.

Wrycza, S. (1999). Analiza i projektowanie systemów informatycznych zarządzania. Metodyki, techniki, narzędzia. Warszawa: Wydawnictwo Naukowe PWN. 